\title{
State budget transfers to Health Insurance Funds for universal health coverage: institutional design patterns and challenges of covering those outside the formal sector in Eastern European high-income countries
}

lleana Vilcu ${ }^{1}$ and Inke Mathauer ${ }^{2^{*}}$

\begin{abstract}
Introduction: Many countries from the European region, which moved from a government financed and provided health system to social health insurance, would have had the risk of moving away from universal health coverage if they had followed a "traditional" approach. The Eastern European high-income countries studied in this paper managed to avoid this potential pitfall by using state budget revenues to explicitly pay health insurance contributions on behalf of certain (vulnerable) population groups who have difficulties to pay these contributions themselves.

The institutional design aspects of their government revenue transfer arrangements are analysed, as well as their impact on universal health coverage progress.

Methods: This regional study is based on literature review and review of databases for the performance assessment. The analytical framework focuses on the following institutional design features: rules on eligibility for contribution exemption, financing and pooling arrangements, and purchasing arrangements and benefit package design.

Results: More commonalities than differences can be identified across countries: a broad range of groups eligible for exemption from payment of health insurance contributions, full state contributions on behalf of the exempted groups, mostly mandatory participation, integrated pools for both the exempted and contributors, and relatively comprehensive benefit packages. In terms of performance, all countries have high total population coverage rates, but there are still challenges regarding financial protection and access to and utilization of health care services, especially for low income people.
\end{abstract}

Conclusion: Overall, government revenue transfer arrangements to exempt vulnerable groups from contributions are one option to progress towards universal health coverage.

Keywords: Universal health coverage, Vulnerable population groups outside formal sector work, Government subsidization of health insurance, State budget transfers, Financial protection

\footnotetext{
*Correspondence: mathaueri@who.int

${ }^{2}$ Department of Health Systems Governance and Financing, World Health

Organization, Avenue Appia, 1211 Geneva, Switzerland

Full list of author information is available at the end of the article
} 


\section{Introduction}

Several countries from Central and Eastern Europe and the former Soviet Union moved from a government financed and provided health system (Semashko model) to social health insurance (SHI) and introduced payroll taxes in the early 1990s (the full list of abbreviations can be found at the beginning of the document) [1]. Prior to this transition, they were characterized by high levels of financial protection and equity in access [2]. This reform would have had the risk of moving away from universal population coverage if implementation had followed a "traditional" SHI approach that would focus on the formal sector employees and their dependents only. The countries covered in this paper mostly managed to avoid this potential pitfall as they transitioned to a contributory health insurance system [3]. In a "traditional" SHI, those not contributing are not covered by the SHI (and thus only access state provided health services). But certain population groups are too poor to pay insurance contributions themselves and they need to be exempted from payment of health insurance contribution in order to remain entitled for health services. Thus, the government budget was the starting point for health financing, and state budget transfers were built into the design of the introduction of earmarked payroll taxes right from the start in nearly all countries. In fact, an increasing number of governments across the globe decide to use general government revenues, i.e. state budget transfers, to explicitly pay the contributions on behalf of non-contributing population groups, most often in addition to cross-subsidization from within the fund's contribution, because they realised that progress towards universal health coverage (UHC) is not possible via payroll taxes of contributors only. This arrangement is also frequently captured and termed as government subsidization of insurance contributions, usually for economically inactive, vulnerable and poor population groups depending on the context [3-7]. Vulnerable groups can be defined as "groups whose demographic, geographic, or economic characteristics impede or prevent their access to health care services" ([8], p. 253).

The specific focus on such budget transfer/subsidization arrangements via some form of health insurance, however, does not suggest that this financing arrangement is the only path to move towards or deepen UHC. One way is to expand user fee exemptions for specific groups, often also called free health-care policies for selected services and/or selected population groups, such as in Africa primarily. Other countries in Eastern and Central Europe and Central Asia have done so without payroll taxes, even though some of them established a separate purchasing agency, such as Latvia. These approaches tend not to be based on the affiliation and enrolment of entitled individuals. In the past, another group of countries tried to rely solely on payroll taxes and SHI to expand coverage without any state budget transfers. But a growing number of countries, both globally as well as in the European region, is applying a mix of contributory and non-contributory approach, by having chosen the path of government subsidization/government budget transfers to a health insurance type system. This deserves a specific analysis which is what this paper chose as its explicit focus.

The paper's aim is to analyse the institutional design features of these government revenue transfer arrangements to $\mathrm{SHI}$ funds that serve to cover non-contributors in the health insurance systems, with a particular emphasis on those outside the formal sector, many of them being the poor and other vulnerable population groups, although it is difficult to separate these from other population groups that are also eligible for contribution exemption. For shortening purpose, from now on we refer to them as "vulnerable groups" or "the exempted". The regional focus of this paper is on Eastern European high-income countries (as per World Bank country income classification [9]).

The existing body of literature contains single country studies, assessing SHI and government subsidization arrangements in particularly or discussing these as part of a broader health system review. Kutzin et al. [10] provide a comprehensive assessment of health financing reforms of former Eastern Bloc countries. Taking it from there, this paper explores in detail the specific institutional design features of SHI arrangements that incorporate government revenue transfer and assesses the progress and achievements or setbacks as to UHC. UHC means that "all people have access to services and do not suffer financial hardship paying for them" ([7], p. 9). The performance assessment also includes a comparison between contributors and the exempt population groups. As a result, those critical institutional design features that are particularly conductive for UHC progress are identified. This analysis reveals that these financing arrangements are indeed one option to progress towards UHC.

The remaining of the paper is structured as follows. The next section outlines the applied methods and describes the analytical framework to research institutional design, as well as UHC related indicators to assess the performance of these financing arrangements. Section 3 presents findings, which is followed by a discussion of potential effects of specific institutional design aspects as well as of challenges on progress towards UHC in Section 4. The last section concludes with policy lessons.

\section{Methods}

This paper's focus is on high-income Eastern European countries of the World Health Organization (WHO) European Region that introduced payroll taxation as a new earmarked tax for a new system of compulsory health insurance combined with government revenue transfers for non-contributors. These countries are 
Croatia, the Czech Republic, Estonia, Hungary, Poland, Slovakia and Slovenia, which were part of the former Eastern Bloc and which have turned into high-income countries over the past years, i.e. that were classified so for at least four consecutive years since 2008 [11]. This paper thus complements a paper by Mathauer et al. [12] of the same subject on low- and middle-income countries of the WHO European Region and is part of a series of regional studies and a global review all with the same research focus on state budget transfer/government subsidization arrangements.

To include or exclude countries in the study, in a first step, former Soviet and Eastern Bloc countries of the WHO European Region which have entered the group of high-income countries and for which the Global Health Expenditure Database indicated social security expenditure in 2012 were selected. In a second step, based on literature screening, countries were included if and when the SHI system was combined with government budget transfers for non-contributors. Once this list of countries was established, a detailed literature search was undertaken for each country in Science Direct, JSTOR, PubMed and Google. In Google, the first five pages, with ten results per page, were screened for publications and grey literature from universities, non-governmental organizations, governments, international organisations and alike. In the case of the other databases the first 100 findings were screened. In addition, the most recent Health Systems in Transition publications were used. For the institutional design analysis, the following search term combinations were used: health system OR health financing OR health insurance OR health vulnerable OR budget transfer OR government revenue transfer OR health subsid* AND the respective country AND/OR fund's name.

The literature search for the performance assessment was based on the following search term combinations: health insurance coverage OR out-of-pocket payments (OOP) OR catastrophic health expenditure OR impov-

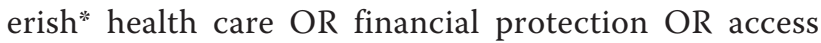
health OR utilization health care OR universal coverage AND the respective country AND/OR fund's name. Furthermore, data was also collected from the WHO (for population size and OOP as a share of total health expenditure (THE)), Organization for Economic Co-operation and Development (OECD) (for the total population coverage rates) and Eurostat (for the share of unmet need) databases, as well as other country statistics.

The analytical framework used to assess institutional design of government subsidization arrangements is guided by the health financing functional approach of Kutzin [13] and looks specifically at the following aspects:
1. Revenue collection:

Eligibility rules for exemption from contributions and targeting;

Financing arrangements;

2. Pooling arrangements;

3. Purchasing arrangements and benefit package design.

The actual design features in place around these functions are the result of explicit or implicit policy choices.

Building upon the World Health Report's UHC conceptualization, progress towards UHC is assessed by looking at changes and improvement in the following three indicators: 1) Population coverage, understood as affiliation to the health financing arrangement under study here; 2) financial protection; and 3) access to and utilization of needed health care services [14]. Table 1 outlines our framework and provides an overview of the institutional design aspects and related policy choices. It also shows how these potentially relate to and affect progress toward UHC. A detailed explanation of these institutional design aspects and indicators can be found in Additional file 1.

\section{Results \\ Country and system overview}

The analysis focuses on seven Eastern European countries, namely Croatia, the Czech Republic, Estonia, Hungary, Poland, Slovakia and Slovenia. Table 2 provides a summary overview of countries. Prior to the system transition of the 1990s, these countries were classified as middle-income countries. During the Soviet Union era, their health systems was based on the Semashko model [15-19] with heavy centralist planning and state owned and financed health facilities ensured high levels of financial protection and equity in access [2].

As part of the transition and health financing reforms, and with the aim to increase resource mobilization as a reaction to economic and state budget challenges, most countries introduced (and a few re-established) payroll taxation for a new system of compulsory SHI. Croatia, Czech Republic, Hungary, Slovakia and Slovenia coupled this with government revenue transfers in the early or mid-1990s, and Poland and Estonia did so in 1999 [20]. In a way, the shift to a SHI system made entitlement in principle contingent upon contributions, or payment of these by the state on behalf of those exempted. Yet, this link between contribution on behalf of the state and entitlement is often less explicit, like in Hungary or Czech Republic [21].

In a first step, entitlement to the health insurance coverage is based on permanent residence (Czech Republic, Estonia, Poland, Slovakia and Slovenia) or 
Table 1 Institutional design features of government revenue transfer/government subsidization

\begin{tabular}{|c|c|}
\hline Institutional design aspect & Related policy choices \\
\hline \multicolumn{2}{|l|}{ Eligibility and enrolment rules } \\
\hline Groups eligible for exemption from contributions/subsidization & $\begin{array}{l}\text { Definition of vulnerability (e.g. children, } \\
\text { unemployed, pregnant women, informal } \\
\text { sector workers, poor, near poor) }\end{array}$ \\
\hline Targeting method & $\begin{array}{l}\text { E.g. universal (based on a very broad } \\
\text { criterion such as residence or no } \\
\text { employment in the formal sector), } \\
\text { indirect (based on socio-demographic, } \\
\text { socio-economic or geographic } \\
\text { characteristics usually correlated with } \\
\text { poverty and vulnerability), direct (through } \\
\text { a means assessment or proxy means testing); } \\
\text { different targeting approaches can be in place } \\
\text { at the same time for different groups }\end{array}$ \\
\hline
\end{tabular}

Intermediate output indicators

UHC related performance

indicators

Enrolment process

Active enrolment by the beneficiary or automatic enrolment by the authorities

Organization responsible for identification of the exempted non-contributors/the subsidized

Type of enrolment/membership

Financing arrangements

Degree of subsidization/co-contribution

E.g., insurance company; central, regional,

local government

Mandatory or voluntary

Full or partial (a co-contribution is required)

Type of transfer mechanism

Individual-based (a specific amount is

being paid for each exempted individual) or lump-sum (a lump sum transfer for the entire exempted population is made)

Calculation logic to determine the amount being transferred

E.g., based on regular contribution levels, minimum or average wages, specific percentage of the government budget, negotiated by the government

Share of the exempted/subsidized within total (insured) population/those being targeted for subsidization (importance of government revenue)

Share of the eligible among the bottom two income quintiles and other vulnerable groups

Share of the exempted/subsidized within total (insured) population; Share of the exempted/subsidized among those being targeted for exemption/subsidization (targeting effectiveness of the system)

Sufficient funding for a comprehensive benefit package

Level of cross-subsidization from contributions
Total population coverage

comprehensiveness of the health insurance system), differentiated along income quintiles

E.g. general government revenues, earmarked government revenues,

transfers from other health insurance funds or from contributors within the same pool (cross-subsidization), donor funding

Financial protection (incidence of catastrophic ${ }^{\mathrm{a}}$ /impoverishing health expenditure), also differentiated along income quintiles and other aspects; Access to services 
Table 1 Institutional design features of government revenue transfer/government subsidization (Continued)

\section{Pooling arrangements}

Type of pool(s) (general)

Type of pool (exempted/subsidized)

Type of health insurance affiliation/membership of the contributors

Purchasing arrangements and benefit package design

Range of services covered by the benefit package

Degree of cost-sharing

Provider payment mechanisms
Single fund or multiple funds

Exempted/subsidized integrated into existing fund(s) or separate fund for the exempted/subsidized

Voluntary or mandatory

E.g. comprehensive, inpatient focus, outpatient focus, pharmaceuticals,

dental care, indirect costs (e.g.

transportation)

Different or same package as contributors

Cost-sharing mechanisms (e.g., co-insurance,

co-payment, deductible) and rates

Type of provider payment and rates

Same or different rules around provider

payment

\section{Degree of fragmentation, \\ Equity in access; \\ Size and composition of pools, \\ Equity in financing;}

Level of cross-subsidization

Efficiency;

Financial protection

Financial protection

Access (utilization rates);

Equity in access

as per the WHO definition, catastrophic expenditure "occurs when a household's total out-of-pocket health payments equal or exceed $40 \%$ of household's capacity to pay" ([46], p. 4) Source of table: adapted from [47] 
Table 2 Country overview

\begin{tabular}{|c|c|c|c|c|c|c|}
\hline Country & $\begin{array}{l}\text { Year of shift to high-income } \\
\text { classification [11] }\end{array}$ & $\begin{array}{l}\text { Population } \\
\text { (2013, in } \\
\text { millions) [48] }\end{array}$ & $\begin{array}{l}\text { GDP per capita } \\
\text { (2013, in current } \\
\text { US\$) [49] }\end{array}$ & $\begin{array}{l}\text { Poverty headcount } \\
\text { ratio (\% of population, } \\
2012)^{\mathrm{a}}[49]\end{array}$ & $\begin{array}{l}\text { Year of } \\
\text { introduction } \\
\text { of (social) health } \\
\text { insurance }\end{array}$ & $\begin{array}{l}\text { Year when budget } \\
\text { transfer to exempt } \\
\text { those unable to } \\
\text { contribute was } \\
\text { introduced }\end{array}$ \\
\hline Croatia & 2008 & 4,3 & 13,597 & 19.5 & 1993 [20] & 1993 [50] \\
\hline Czech Republic & 2006 & 10,5 & 19,858 & 8.6 & 1992 [51] & 1992 [51] \\
\hline Estonia & 2006 & 1,3 & 18,877 & 18.6 & 1992 [51] & 1999 [16] \\
\hline Hungary & 2007 & 9,9 & 13,485 & 14.3 & 1990 [52] & 1990 [52] \\
\hline Poland & 2009 & 38,5 & 13,653 & 17.3 & 1999 [51] & 1999 [51] \\
\hline Slovakia & 2007 & 5,4 & 18.049 & 12.8 & 1994 [22] & 1994 [22] \\
\hline Slovenia & 1997 & 2,1 & 23,295 & 14.5 & 1992 [23] & 1992 [23] \\
\hline
\end{tabular}

Legend: GDP gross domestic product

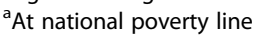

personal identification card (Hungary). As a second condition, definition of specific groups eligible for exemption from contributions are specified by law $[16-18,22-24]$.

\section{Eligibility and targeting to identify the exempted}

For the European region, it is important to specify the terminology of eligibility. Whereas in other regions, it is appropriate to talk of the "subsidized", the European region requires some further terminological specification. As everybody was covered prior to the transition, the introduction of payroll taxes for formal sector employees and a contributory SHI system implied that various population groups needed to be exempted from contributions while still remaining entitled. The transfer of government revenues on behalf of and for the exempt has also led to the term of the "state insured".

An overview of eligibility rules for those exempted from contributions in each country are provided in Table 3, revealing strong commonalities as well as some distinct differences in a few countries. The population group most frequently exempted are the economically inactive people [22]. The exempted or state insured need to be distinguished from the insured family dependents who are covered via their principal affiliate through the principle of cross-subsidization by contributors. Family dependents usually include non-working spouses and children. Yet, in Croatia, Czech Republic, Hungary and Poland, children are actually part of the state insured for which the government provides explicit budget transfers.

While the categories of exempt persons are diverse, the most common population groups include the unemployed, pensioners, people receiving social assistance benefits, the poor and children below 18 years. Even though military personnel, who are employed by the Ministry of Defence, may be not considered as vulnerable, they are exempted from contributions in several countries (Croatia, Czech Republic, Estonia and Hungary). Estonia stands out to some extent: in addition to the groups for whom the government transfers revenues to the insurance fund, several population groups do not contribute and for which there is no state budget transfer made to contribute on their behalf. These encompass children up to 19 years, students, non-working pregnant women, non-working spouses of insured individuals, pensioners and disabled people entitled to special pensions. As in Croatia prior to its 2002 reform as in many Western European countries, this reflects the idea of insurance coverage of family dependents being cross-subsidized by the contributors.

Table 4 provides an overview of the targeting and enrolment rules. Notably, most countries apply indirect targeting to identify eligible individuals for contribution exemption, based on socio-economic characteristics. Only Hungary and Poland use a direct targeting approach based on income means testing. The organization responsible for the identification of eligible population groups is most often the local government authority. Nonetheless, the identified eligible need to undertake active steps for their enrolment into the SHI in several countries.

\section{Financing arrangements}

Two key health expenditure indicators related to the financing arrangements are general government health expenditure (GGHE) as a share of THE and expenditure of SHI funds as a share of GGHE (Table 5).

GGHE as a share of THE is relatively high in 1995, but decreases in all countries, reaching the lowest level in Hungary at $64 \%$ (from $84 \%$ in 1995). The core purchaser of health services are the SHI agencies, as at least $80 \%$ of GGHE is spent via them, and in three countries, this share is above $90 \%$. This share has mostly gone up, slightly though, in four of the seven countries, ranging from $83 \%$ in Hungary to $94 \%$ in Croatia. Importantly, this share includes the government revenue transfers. While precise data is only available for 
Table 3 Eligible groups for exemption from contribution

\begin{tabular}{|c|c|c|c|c|c|}
\hline Country & $\begin{array}{l}\text { Terminology used for } \\
\text { eligible groups }\end{array}$ & Eligible groups for exemption from contributions & & $\begin{array}{l}\text { Family insurance } \\
\text { in place }\end{array}$ & $\begin{array}{l}\text { Type of membership } \\
\text { of the exempt }\end{array}$ \\
\hline \multirow[t]{4}{*}{ Croatia } & \multirow[t]{4}{*}{ Vulnerable [50] } & Unemployed; & War veterans; & \multirow[t]{4}{*}{ Yes [50] } & \multirow[t]{4}{*}{ Mandatory [50] } \\
\hline & & Disabled persons; & Militaries; & & \\
\hline & & Children < 18 years; & $\begin{array}{l}\text { Pensioners with pensions below } \\
\text { the average net wage; }\end{array}$ & & \\
\hline & & Students; & Farmers above age $66[28,29]$ & & \\
\hline \multirow[t]{5}{*}{ Czech Republic } & \multirow[t]{5}{*}{ State insured [24] } & Unemployed; & $\begin{array}{l}\text { Women taking care of one } \\
\text { child }<7 \text { years or more } \\
\text { children }<15 \text { years; }\end{array}$ & \multirow[t]{5}{*}{ Yes [24] } & \multirow[t]{5}{*}{ Mandatory [24] } \\
\hline & & Pensioners; & Military personnel; & & \\
\hline & & Children; & Prisoners; & & \\
\hline & & Students; & People receiving social welfare; & & \\
\hline & & Women or men on parental leave; & Asylum seekers [31] & & \\
\hline \multirow[t]{6}{*}{ Estonia } & \multirow[t]{6}{*}{ Insured covered by state [16] } & Individuals on parental leave with children $<3$ years; & $\begin{array}{l}\text { Individuals exposed to nuclear } \\
\text { contamination, mainly related } \\
\text { to the Chernobyl nuclear accident; }\end{array}$ & \multirow[t]{6}{*}{ Yes [16] } & \multirow[t]{6}{*}{ Mandatory [16] } \\
\hline & & One non-working parent of children $<8$ years; & People receiving social benefits; & & \\
\hline & & $\begin{array}{l}\text { One parent in families with three } \\
\text { children }<19 \text { years; }\end{array}$ & Dependent spouses of diplomats; & & \\
\hline & & Carers of disabled people; & \multirow{3}{*}{$\begin{array}{l}\text { Registered unemployed (entitlement } \\
\text { for } 270 \text { days) [16] }\end{array}$} & & \\
\hline & & Military personnel; & & & \\
\hline & & $\begin{array}{l}\text { Non-contributing insured people (almost half of insured people): } \\
\text { disabled people entitled to special pensions, students, non-w } \\
\text { non-working pregnant women from the } 12 \text { th week of pregna }\end{array}$ & & & \\
\hline \multirow[t]{5}{*}{ Hungary } & \multirow[t]{5}{*}{ Non-contributing groups [17] } & Pensioners; & People with disability; & \multirow[t]{5}{*}{ Yes [17] } & \multirow[t]{5}{*}{ Mandatory [52] } \\
\hline & & Women on maternity leave; & Children $<18$ years; & & \\
\hline & & People with very low income (including homeless persons); & Students; & & \\
\hline & & Military personnel; & Roma population $[17,43,52]$ & & \\
\hline & & The dependants of all the above; & & & \\
\hline \multirow[t]{5}{*}{ Poland } & \multirow[t]{5}{*}{ Non-contributing groups [18] } & Children $<18$ years; & People not eligible for unemployment benefits; & \multirow[t]{5}{*}{ Yes [18] } & \multirow[t]{5}{*}{ Mandatory [18] } \\
\hline & & Pregnant women; & People with low income; & & \\
\hline & & Individuals with disabilities; & Soldiers; & & \\
\hline & & \multirow{2}{*}{$\begin{array}{l}\text { People above age } 65 \text { without an old age } \\
\text { or disability pension; }\end{array}$} & Farmers; & & \\
\hline & & & People on parental leave $[18,53]$ & & \\
\hline
\end{tabular}

One parent in families with three

Military personne

Non-contributing insured people (almost half of insured people): children up to 19 years, pensioners, disabled people entitled to special pensions, students, non-working spouses of insured individuals,

People with disability

Students;

Military personnel;

People on parental leave $[18,53]$ 
Table 3 Eligible groups for exemption from contribution (Continued)

\begin{tabular}{llll}
\hline Slovakia & State insured [22] & Dependent children and their carers; & Reservists; \\
& & Pensioners; & Unemployed; \\
& & Job applicants not receiving any allowance; & People on sick leave [22, 54] \\
& Persons receiving disability benefits; & \\
Slovenia & No specific term [23] & Individuals without income; & Unregistered unemployed; \\
& & Prisoners; & Recipients of social security allowances [23, 55] \\
& War veterans; & \\
\hline
\end{tabular}


Table 4 Targeting and enrolment rules

\begin{tabular}{llll}
\hline Country & Targeting method applied & $\begin{array}{l}\text { Responsible organization } \\
\text { for identifying the eligible }\end{array}$ & Initiation of enrolment process \\
\hline Croatia & Indirect targeting [50] & Local and central government [29] & n/a \\
Czech Republic & Indirect targeting [24] & Central government [24] & Active enrolment by the beneficiary [24] \\
Estonia & Indirect targeting [16] & Regional government [16] & Automatic enrolment by authorities [16] \\
Hungary & Indirect targeting and & Local government [17] & Active enrolment by the beneficiary [52] \\
& direct targeting (means & & \\
& testing) of people with & & n/a \\
Poland & Indirect targeting and & Local government [18] & \\
& direct targeting (means & & \\
testing) of people with & low income [18] & & Active enrolment by the beneficiary [22] \\
Slovakia & Indirect targeting [22] & Local government [22] & n/a \\
Slovenia & Indirect targeting [23] & Local government [23] & \\
\hline
\end{tabular}

Hungary, Slovakia and Estonia, general government revenue transfer to the insurance funds do constitute an important share in all countries. In Hungary, the share of general government revenue as of total SHI funds is largest (above $50 \%$ ) [25], followed by Slovakia (34 \% in 2011) [26]. It is important to note though that budget transfers are not necessarily linked only to finance the non-contributors, but may equally serve to provide funding to the whole pool of both contributors and noncontributors. In Hungary, for example, it is also a means to complement government taxation policy to reduce contribution rates for the contributors. Estonia is an exception again, as this share is approximately $5 \%$ only (in 2012) [27], given that the non-contributors are largely cross-subsidized from contributors.

The institutional design features relating to the financing arrangements are presented in the first four columns of Table 5. Importantly, in contrast to other regions, all countries studied here fully exempt those considered as unable to pay contributions, i.e. eligible for exemption, and they do not co-contribute at all. This aspect is crucial, because the collection of partial contributions from those outside formal sector employment may be cumbersome and potentially hinder vulnerable groups to get enrolled.

However, some groups outside the formal sector are not eligible for exemption, i.e. no specific state budget transfers are made on their behalf. These groups have to make contributions and in some countries include the registered unemployed, farmers, craftsmen, pensioners and the self-employed.

Table 5 also presents the logic or formula of determining the amount of the state budget transfer for noncontributors. In all countries but two, the government transfer for the exempted is based on a per capita amount that is formula-based. One exception is Hungary, where the government transfers a lump sum that is largely a result of budget negotiation processes [17]. This is also the case for all non-contributors of Croatia except those who receive unemployment benefits or pensions below the average net wage.

Various types of calculation formula and logics are found. First, in the Czech Republic and Slovakia, the transfer amount is determined by applying a set rate to the average wage, or as in Estonia, on an annually defined amount. Yet, notably, in Slovakia, the contribution rate for the contributing population is $14 \%$ [22], whereas a rate of $4.78 \%$ is applied for the exempt groups, pointing to crosssubsidization from contributors to the exempt. Secondly, in Poland, Croatia and Estonia, for social security beneficiaries, such as pensioners and the unemployed, the transfer amount is calculated by applying a set rate to social security pension or unemployment benefits, even though the source of funds are central government revenues, except in Estonia. A third way is applied in Slovenia where a fixed amount per capita is in place.

In all these countries, the transfer amount for the state insured has hence little to do with the average contribution amount of the contributors. Yet, this is not the objective. Different contribution rates applied to different "contribution" bases for different population groups within the same country are thus largely the result of taxation policy considerations as well as feasibility concerns. Importantly, these calculation formula are not intended to reflect an actuarial-based contribution to cover the exempted average expenditure. Instead, the aim is to achieve a funding level, in combination with contributions that cover the costs of care. Thus, in some countries, government budget transfers serve to "subsidize" all insured, whether contributing or not.

Regarding the source of transfers, all countries make use of central government revenues. Only in Estonia are unemployment funds the source of funds transferred for the registered unemployed. Moreover, a few countries make use of hypothecated taxes: in Croatia, since 2008, 
Table 5 Financing arrangements and health expenditure indicators

\begin{tabular}{|c|c|c|c|c|c|c|c|c|c|c|}
\hline \multirow[t]{2}{*}{ Country } & \multirow[t]{2}{*}{$\begin{array}{l}\text { Degree of } \\
\text { exemption }\end{array}$} & \multirow{2}{*}{$\begin{array}{l}\text { Logic/formula to calculate } \\
\text { the transfer amount for the } \\
\text { non-contributors }\end{array}$} & \multirow[t]{2}{*}{ Transfer mechanism } & \multirow[t]{2}{*}{$\begin{array}{l}\text { Financing source of } \\
\text { transfer }\end{array}$} & \multicolumn{3}{|c|}{ GGHE as \% of THE [48] } & \multicolumn{3}{|c|}{$\begin{array}{l}\text { Expenditures of social health insurance fund } \\
\text { as \% of GGHE }[48]\end{array}$} \\
\hline & & & & & 1995 & $\begin{array}{l}\text { Year prior to intro-duction } \\
\text { of govt budget transfers }\end{array}$ & 2013 & 1995 & $\begin{array}{l}\text { Year prior to intro-duction } \\
\text { of govt budget transfers }\end{array}$ & 2013 \\
\hline \multirow[t]{3}{*}{ Croatia } & \multirow[t]{3}{*}{$100 \%[28]$} & $\begin{array}{l}\text { Pensioners with pensions } \\
\text { below the average net wage: } \\
1 \% \text { of gross pension }\end{array}$ & $\begin{array}{l}\text { Individual-based } \\
\text { for pensioners } \\
\text { and unemployed }\end{array}$ & $\begin{array}{l}\text { General taxation } \\
\text { for pensioners } \\
\text { and unemployed; }\end{array}$ & \multirow[t]{3}{*}{86} & \multirow[t]{3}{*}{$\mathrm{n} / \mathrm{a}$} & \multirow[t]{3}{*}{80} & \multirow[t]{3}{*}{95} & \multirow[t]{3}{*}{$\mathrm{n} / \mathrm{a}$} & \multirow[t]{3}{*}{94} \\
\hline & & $\begin{array}{l}\text { Unemployed: } 5 \% \text { of } \\
\text { unemployment benefit [28] }\end{array}$ & \multirow[t]{2}{*}{$\begin{array}{l}\text { Lump sum for } \\
\text { the rest [20] }\end{array}$} & \multirow{2}{*}{$\begin{array}{l}\text { Central and local } \\
\text { governments budget } \\
\text { for the rest [28] }\end{array}$} & & & & & & \\
\hline & & $\begin{array}{l}\text { The rest: lump sum decided } \\
\text { upon in the budget-making } \\
\text { process [20] }\end{array}$ & & & & & & & & \\
\hline Czech Republic & $100 \%[24]$ & $\begin{array}{l}\text { Contribution rate of } 13.5 \% \\
\text { applied to } 25 \% \text { of the average } \\
\text { monthly wage two years prior } \\
\text { to the current year [24] }\end{array}$ & $\begin{array}{l}\text { Individual-based } \\
\text { [24] }\end{array}$ & $\begin{array}{l}\text { Central government } \\
\text { budget [19] }\end{array}$ & 91 & $\mathrm{n} / \mathrm{a}$ & 83 & 84 & $\mathrm{n} / \mathrm{a}$ & 93 \\
\hline \multirow[t]{2}{*}{ Estonia } & \multirow[t]{2}{*}{$100 \%[16]$} & $\begin{array}{l}\text { For the registered unemployed: } \\
13 \% \text { of an annually defined } \\
\text { amount }\end{array}$ & \multirow[t]{2}{*}{$\begin{array}{l}\text { Individual-based } \\
\text { [16] }\end{array}$} & $\begin{array}{l}\text { Unemployment } \\
\text { insurance fund }\end{array}$ & \multirow[t]{2}{*}{90} & \multirow[t]{2}{*}{86 (1998) } & \multirow[t]{2}{*}{78} & \multirow[t]{2}{*}{86 (1999) } & \multirow[t]{2}{*}{$\mathrm{n} / \mathrm{a}$} & \multirow[t]{2}{*}{87} \\
\hline & & $\begin{array}{l}\text { The rest: } 13 \% \text { of an annually } \\
\text { defined amount [16] }\end{array}$ & & $\begin{array}{l}\text { Central government } \\
\text { budget [40] }\end{array}$ & & & & & & \\
\hline Hungary & $100 \%[17]$ & Not specified [20] & Lump sum [17] & $\begin{array}{l}\text { Central government } \\
\text { budget [17] }\end{array}$ & 84 & $\mathrm{n} / \mathrm{a}$ & 64 & 80 & $\mathrm{n} / \mathrm{a}$ & 83 \\
\hline Poland & $100 \%$ [18] & $\begin{array}{l}\text { Calculated on the basis of } \\
\text { unemployment benefits [18] }\end{array}$ & $\begin{array}{l}\text { Individual-based } \\
\text { [18] }\end{array}$ & $\begin{array}{l}\text { Central government } \\
\text { budget [18] }\end{array}$ & 73 & 65 (1998) & 70 & 84 (1999) & 0 (1998) & 86 \\
\hline Slovakia & $100 \%[22]$ & $\begin{array}{l}4.78 \% \text { of national average } \\
\text { wage [22] }\end{array}$ & $\begin{array}{l}\text { Individual-based } \\
\text { [22] }\end{array}$ & $\begin{array}{l}\text { Central government } \\
\text { budget [22] }\end{array}$ & 89 & $\mathrm{n} / \mathrm{a}$ & 70 & 96 & $\mathrm{n} / \mathrm{a}$ & 90 \\
\hline Slovenia & $100 \%[23]$ & Fixed amount [23] & $\begin{array}{l}\text { Individual-based } \\
\text { [23] }\end{array}$ & $\begin{array}{l}\text { Central government } \\
\text { budget, municipalities [23] }\end{array}$ & 78 & $\mathrm{n} / \mathrm{a}$ & 72 & 94 & $\mathrm{n} / \mathrm{a}$ & 93 \\
\hline
\end{tabular}

Legend: GGHE general government health expenditure; THE total health expenditure

${ }^{a}$ This figure includes the government revenue transfers 
car insurance tax and $32 \%$ of revenues from excise taxes on tobacco are designated to health financing [28, 29]. Hungary also introduced earmarked taxes for health financing, such as the fat taxes levied on foods with high fat, sugar, salt and caffeine content [30].

\section{Pooling arrangements}

Strong commonalities in institutional design are found with respect to pooling arrangements (Table 6). As the countries transitioned and shifted from a universalist Semashko system (covering all population groups) to a compulsory SHI system, the most crucial feature is that all countries built in universality and chose to establish an integrated fund for both the contributors and noncontributors with the aspiration and logic to again cover the total population. While this followed the pre-transition logic of coverage for all, setting up an integrated pool for all population groups is not self-evident, as evidence from other regions reveals.

This came along with another important policy choice, namely to introduce mandatory coverage for all - both contributors as well as non-contributors - except in Estonia and Poland, where a few smaller population groups can obtain insurance coverage on a voluntary basis.

Even though contributors and exempt are within the same pool, there is fragmentation in some countries. While Croatia, Estonia, Hungary, Poland and Slovenia have a single national pool, the Czech Republic and Slovakia introduced a multiple payer system at a later stage, with 9 funds [31] and 3 funds [22] respectively, combined with a risk equalization mechanism. In the Czech Republic, each health insurance fund collects the SHI contributions from all its members, or receives state budget transfers for the state insured. Individuals are free to enrol in any health insurance fund and they have the right to choose it once a year [24]. In 1994, the government introduced a risk adjustment mechanism to equalize available funds across insurers. The revenues subject to the risk adjustment mechanism comprised $100 \%$ of state transfers on behalf of the state insured and $60 \%$ of revenues from contributors. These funds were redistributed among insurers taking into account the number of state insured persons, further adjusted by two age categories (below and above 60 years). Those above 60 years of age are given a triple weight in the risk adjustment formula [32]. Although this approach allowed for more financial sustainability, it was ineffective because it did not eliminate incentives for risk selection [32]. Thus, in the late 2000s, the risk adjustment mechanisms was further modified, with $100 \%$ of revenues from contributions being subject to redistribution and with a risk adjustment formula now based on age and gender, and no longer on exemption status. This further reduced incentives for risk selection [24].

In Slovakia, soon after the introduction of its SHI, competition between non-profit insurers was introduced [32]. Since 2010, after merging and various reforms in the legal status of the funds, the system ended up having three health insurance funds. Each collects SHI contributions and receives government revenue transfers, and individuals are free to enrol in any of them. A risk adjustment mechanism has been set up, initially based on an age- and gender-related risk index, which, since 2010, is applied in a differential way for the state insured and the contributors. The different risk-adjusted allocations for different population groups result in certain groups of the state insured being more attractive (e.g., students) than others (e.g., unemployed), possibly increasing incentives for risk selection by insurers [22].

Table 6 Pooling arrangements

\begin{tabular}{|c|c|c|c|}
\hline Country & Single/multiple pool(s) & $\begin{array}{l}\text { Integrated/separated pool } \\
\text { for the exempt and contributors }\end{array}$ & Type of membership of contributors \\
\hline Croatia & Single: Croatian Health Insurance Institute [56] & Integrated [56] & Mandatory [50] \\
\hline Czech Republic & Multiple [24] & Integrated [24] & Mandatory [24] \\
\hline \multirow[t]{2}{*}{ Estonia } & \multirow[t]{2}{*}{ Single: Estonian Health Insurance Fund [57] } & \multirow[t]{2}{*}{ Integrated [57] } & Mandatory \\
\hline & & & $\begin{array}{l}\text { Voluntary: residents who receive a pension from } \\
\text { abroad, unregistered unemployed, students } \\
\text { studying beyond normal length of study [16] }\end{array}$ \\
\hline Hungary & $\begin{array}{l}\text { Single: Health Insurance Fund, administrated } \\
\text { by the National Health Insurance Fund } \\
\text { Administration [17] }\end{array}$ & Integrated [17] & Mandatory [17] \\
\hline \multirow[t]{2}{*}{ Poland } & \multirow[t]{2}{*}{ Single: National Health Fund [53] } & \multirow[t]{2}{*}{ Integrated [18] } & Mandatory \\
\hline & & & $\begin{array}{l}\text { Voluntary for employees on unpaid leave, } \\
\text { persons engaged in certain types of contract } \\
\text { work, volunteers [18] }\end{array}$ \\
\hline Slovakia & Multiple [22] & Integrated [22] & Mandatory [22] \\
\hline Slovenia & Single: Health Insurance Institute of Slovenia [23] & Integrated [23] & Mandatory [23] \\
\hline
\end{tabular}


Purchasing arrangements and benefit package design

Since all countries operate integrated schemes for both contributors and the exempt, provider payment mechanisms and rates applied are the same for both groups, thus giving providers no immediate incentive for cream-skimming patients.

As Table 7 shows, in all the countries covered here, the SHI benefit package is relatively comprehensive and covered health services are the same for both the noncontributors and contributors. Where covered services offered at private health care providers are included, access for the state insured is the same as for contributors.

Although the range of covered health care benefits is broad in all countries, cost-sharing mechanisms are in place, with an overview provided in Table 8. However, most countries provide cost-sharing exemptions for some but not all state insured groups and non-contributors as well as some groups among the contributors.

\section{Assessment of UHC related performance indicators Population coverage}

This section seeks to explore how countries fared on their path to universal health since they shifted to the hybrid financing system of SHI and state budget

Table 7 Benefit package

\begin{tabular}{|c|c|c|}
\hline \multirow[t]{2}{*}{ Country } & \multicolumn{2}{|l|}{ Range of services covered } \\
\hline & & $\begin{array}{l}\text { Same/different } \\
\text { compared to } \\
\text { the contributors }\end{array}$ \\
\hline Croatia & $\begin{array}{l}\text { Comprehensive: primary } \\
\text { care, inpatient and outpatient } \\
\text { care, list of prescribed drugs, } \\
\text { selected dental procedures [56] }\end{array}$ & Same [56] \\
\hline Czech Republic & $\begin{array}{l}\text { Comprehensive: outpatient } \\
\text { and inpatient care, prescription } \\
\text { drugs, selected drugs, rehabilitation, } \\
\text { selected dental procedures, } \\
\text { sanatoria treatment [24] }\end{array}$ & Same [24] \\
\hline Estonia & $\begin{array}{l}\text { Comprehensive: family doctor } \\
\text { services, inpatient and outpatient } \\
\text { specialist care, long-term care, } \\
\text { rehabilitation, prescribed drugs [39] }\end{array}$ & Same [16] \\
\hline Hungary & $\begin{array}{l}\text { Comprehensive: primary care, } \\
\text { secondary and tertiary care, drugs, } \\
\text { selected dental care services [17] }\end{array}$ & Same [17] \\
\hline Poland & $\begin{array}{l}\text { Comprehensive: primary health } \\
\text { care, outpatient specialist care, } \\
\text { hospital treatment, psychiatric care } \\
\text { and addiction treatment, certain } \\
\text { dental care services, drugs [18] }\end{array}$ & Same [18] \\
\hline Slovakia & $\begin{array}{l}\text { Comprehensive: inpatient and } \\
\text { outpatient care, selected drugs, } \\
\text { basic dental care services [22] }\end{array}$ & $\mathrm{n} / \mathrm{a}$ \\
\hline Slovenia & $\begin{array}{l}\text { Comprehensive: primary, secondary } \\
\text { and tertiary services, drugs, medical } \\
\text { devices, costs of travel to health } \\
\text { facilities [23] }\end{array}$ & Same [23] \\
\hline
\end{tabular}

transfers. It starts by looking at total population enrolment rates. The population enrolled in $\mathrm{SHI}$ as a share of the whole population is above $99 \%$ in 2 out of the 7 analysed countries (Czech Republic and Slovenia). For the other countries their population coverage rate is equally very high and above $90 \%$ (see Table 9).

Data on the share of the exempt or state insured as of the total population is not available for all countries. Estimations suggest that the largest share is found in Croatia (64\%), followed by Slovakia (approx. $62 \%$ ) and the Czech Republic (58 \%) [19]. Estonia has the lowest share of $4.9 \%$, but this needs to be seen in addition to the $45.8 \%$ of the non-contributing population being cross-subsidized by contributors. These figures indicate the significance of exemption and non-contribution and the importance of government revenue transfers.

An important question is which type of people are not covered in the countries with a population coverage rate below $100 \%$ and whether they fall outside the eligible groups for exemption or non-contribution. In fact, people of Roma ethnic groups may be most likely to remain uninsured. In 2011, 7 \% of the Roma population in the Czech Republic was not covered by the SHI [33], $9 \%$ in Hungary [34], and $3 \%$ in Slovakia respectively [35]. However, these numbers are small in absolute terms considering that the Roma population represents approximately $3 \%$ of the total population in the Czech Republic [33] and $2 \%$ in Hungary and Slovakia [26].

In Estonia, the long-term unemployed and men that do not belong to the economically active population between 30 and 50 years old are not part of the defined eligible groups for non-contributions and are thus more likely not to be insured [36]. In the richest income quintile every tenth person was found to not have insurance, whereas the probability of being uninsured is four times higher among people in the lowest income quintile [16]. In Poland, approximately $1-2 \%$ of the population, namely the very poor, are uninsured. However, since 2004, regardless of insurance status, very poor people as well as uninsured pregnant women and children below 18 years have access, though limited, to free publiclyfinanced health services [37].

Finally, a very small percentage of the population is not covered, because these individuals are insured in other EU Member States (e.g. in Slovakia, this is $2.4 \%$ of population [22]).

\section{Financial protection}

Financial protection data that differentiates between contributors and non-contributors is not available. Therefore, this and the following sub-section also assess data differentiated along income quintiles, although non-contributors cannot be simply equated with low income quintile population groups. Nonetheless, looking 
Table 8 Cost-sharing arrangements

\begin{tabular}{|c|c|c|}
\hline Country & Co-payments/coinsurance/benefit ceiling & Groups exempted from cost-sharing \\
\hline \multirow[t]{2}{*}{ Croatia } & $\begin{array}{l}\text { Co-payments for inpatient and outpatient hospital services } \\
\text { ( } 20 \% \text { of price), dental services ( } 20 \% \text { of price), primary care, } \\
\text { prescribed drugs }\end{array}$ & \multirow[t]{2}{*}{$\begin{array}{l}\text { Children, pregnant women, people living below the } \\
\text { poverty line are exempted from co-payments [28] }\end{array}$} \\
\hline & Price cap for all co-payments [28] & \\
\hline \multirow[t]{3}{*}{ Czech Republic } & $\begin{array}{l}\text { Co-payments for dental care, medical aids, and some prescribed } \\
\text { drugs }\end{array}$ & \multirow[t]{3}{*}{$\begin{array}{l}\text { Children and adolescents up to the age of } 18 \text { years } \\
\text { are exempted from user fees for doctor visits [24] }\end{array}$} \\
\hline & $\begin{array}{l}\text { User fees for doctor visits, hospitals stays, prescription drugs and } \\
\text { the use of outpatient services outside the regular office hours } \\
\text { (annual ceiling per insured individual) }\end{array}$ & \\
\hline & $\begin{array}{l}\text { Children and adolescents up to the age of } 18 \text { and people older than } \\
\text { 65: lower annual ceiling [24] }\end{array}$ & \\
\hline \multirow[t]{2}{*}{ Estonia } & $\begin{array}{l}\text { Co-payments for outpatient specialist care (if contracted by health } \\
\text { insurance), inpatient care, prescription drugs, prescribed drugs, } \\
\text { dental care (except tooth preservation) }\end{array}$ & \multirow[t]{2}{*}{$\mathrm{n} / \mathrm{a}$} \\
\hline & $\begin{array}{l}\text { Co-insurance for specific inpatient care services set by the Estonian } \\
\text { Health Insurance Fund }[16,40]\end{array}$ & \\
\hline \multirow[t]{2}{*}{ Hungary } & $\begin{array}{l}\text { Co-payments and co-insurance for drugs, medical aids and prostheses, } \\
\text { balneotherapy, dental prostheses, treatment in sanatoria, long-term } \\
\text { chronic care, some 'hotel' aspects of inpatient services }\end{array}$ & \multirow[t]{2}{*}{$\mathrm{n} / \mathrm{a}$} \\
\hline & $\begin{array}{l}\text { Co-payments for non-referral specialist services, except in emergency } \\
\text { cases; co-payments for services beyond the doctor's recommended } \\
\text { treatment [17] }\end{array}$ & \\
\hline \multirow[t]{2}{*}{ Poland } & $\begin{array}{l}\text { Cost-sharing for drugs, certain dental procedures and material, certain } \\
\text { health resort services }\end{array}$ & \multirow{2}{*}{$\begin{array}{l}\text { Veterans with disabilities and their spouses if they are } \\
\text { dependant, veterans' widows or widowers if they are } \\
\text { entitled to a survivor's pension are exempted from } \\
\text { co-payment [18] }\end{array}$} \\
\hline & Co-payments for orthopaedic devices [18] & \\
\hline \multirow[t]{2}{*}{ Slovakia } & $\begin{array}{l}\text { User fees for prescriptions (drugs, medical devices) and various health } \\
\text { services beyond primary and secondary outpatient care and inpatient } \\
\text { care. }\end{array}$ & \multirow[t]{2}{*}{$\begin{array}{l}\text { People with disabilities and children under } 6 \text { years are } \\
\text { exempted from co-payments [54] }\end{array}$} \\
\hline & $\begin{array}{l}\text { Co-payments for drugs, sanatoria treatment and transport to health } \\
\text { service [22] }\end{array}$ & \\
\hline Slovenia & $\begin{array}{l}\text { Co-payments for visits to GP, specialists, hospitals and laboratories for } \\
\text { the use of services covered by the Health Insurance Institute of } \\
\text { Slovenia [23] }\end{array}$ & $\begin{array}{l}\text { Children, unemployed individuals, those with income } \\
\text { below a certain threshold and chronically ill people are } \\
\text { exempted from co-payments [23] }\end{array}$ \\
\hline
\end{tabular}

at income quintile differences helps revealing inequities across the whole population.

Table 10 summarizes data on OOP expenditure. The OOP health expenditures as share of THE vary across the analysed countries, ranging from $12 \%$ in Slovenia to $28 \%$ in Hungary, which is very low in global comparison. Only in Poland did this share decrease, and in Croatia and Estonia only very marginally, since the introduction of the SHI system including its government revenue transfers. Data regarding the share of OPPs as household expenditure by income quintile or decile is only available for a few countries. In the Czech Republic, OOPs are low and distributed relatively even across household income deciles, in contrast to Estonia, Hungary and Slovakia, where financial protection of low income quintiles is a real concern.

Data to reveal changes and disaggregation in the incidence of catastrophic and impoverishing expenditure is scarce (Table 11). In Hungary, both indicators show a slight improvement, so does the incidence for impoverishing expenditure in Poland. In contrast, in the Czech Republic, incidence of catastrophic expenditure increased slightly, whereas in Estonia, it is fluctuating with no clear trend, while its incidence of impoverishing expenditure for the two bottom income quintiles seems to go down over the recent years.

\section{Access to and utilization of health care services}

Table 12 provides data on utilization rates of health services across countries. Utilization rates of general practitioners (GP) services are equitable along income quintiles in 3 out of 7 countries (Czech Republic, Hungary and Slovenia). With respect to dental care, utilization rates are equitable in the Czech Republic and Slovenia, while in Croatia, Estonia, Hungary and Poland there is some inequity, with high-income people being advantaged.

In 2012, in all countries, except Slovenia where data is not available, within the poorest income quintile, the percentage of people reporting unmet needs for medical examination is higher in comparison to better-off 
Table 9 Population coverage rates

\begin{tabular}{|c|c|c|c|c|c|c|}
\hline \multirow[t]{2}{*}{ Country } & \multirow{2}{*}{$\begin{array}{l}\text { (Social) health } \\
\text { insurance enrolment } \\
\text { rateof total population }\end{array}$} & \multirow{2}{*}{$\begin{array}{l}\text { Population groups among which } \\
\text { some individuals are more likely } \\
\text { not to be enrolled }\end{array}$} & \multicolumn{3}{|l|}{ Exempted as share of } & \multirow[t]{2}{*}{ Year } \\
\hline & & & Total population & $\begin{array}{l}\text { Insured } \\
\text { population }\end{array}$ & $\begin{array}{l}\text { Eligible } \\
\text { population }\end{array}$ & \\
\hline Croatia & $98.4 \%[58]$ & $\mathrm{n} / \mathrm{a}$ & $64 \%^{\mathrm{b}}[28]$ & $65 \%^{b}$ & $\mathrm{n} / \mathrm{a}$ & 2008 \\
\hline Czech Republic & $99.9 \%^{\mathrm{b}}$ & $\begin{array}{l}\text { Individuals from the Roma ethnic } \\
\text { group [33] }\end{array}$ & $58 \%[19,31]$ & $58 \%[19]$ & $100 \%$ & 2011 \\
\hline \multirow[t]{2}{*}{ Estonia } & \multirow[t]{2}{*}{$93.9 \%[59]$} & Long-term unemployed & \multirow[t]{2}{*}{$4.9 \%^{b}(2011)[27]$} & \multirow[t]{2}{*}{$5.3 \%^{\mathrm{b}}(2011)[27]$} & \multirow[t]{2}{*}{$\mathrm{n} / \mathrm{a}$} & \multirow[t]{2}{*}{2014} \\
\hline & & $\begin{array}{l}\text { Men that do not belong to the } \\
\text { economically active population } \\
\text { between } 30 \text { and } 50 \text { years [36] }\end{array}$ & & & & \\
\hline Hungary & $96.0 \%[59]$ & Individuals from the Roma ethnic group [34] & $\mathrm{n} / \mathrm{a}$ & $\mathrm{n} / \mathrm{a}$ & $n / a$ & 2013 \\
\hline \multirow[t]{4}{*}{ Poland } & \multirow[t]{4}{*}{$91.6 \%[59]$} & Poor & \multirow[t]{4}{*}{$n / a$} & \multirow[t]{4}{*}{$\mathrm{n} / \mathrm{a}$} & \multirow[t]{4}{*}{$\mathrm{n} / \mathrm{a}$} & \multirow[t]{4}{*}{2013} \\
\hline & & Homeless & & & & \\
\hline & & Children of uninsured parents & & & & \\
\hline & & Youngsters kept in holding facilities [37] & & & & \\
\hline Slovakia & $94.6 \%[59]$ & Individuals from the Roma ethnic group [35] & $61.5 \%^{\mathrm{b}}(2011)[26]$ & $63.5 \%^{\mathrm{b}}(2011)[26]$ & $\mathrm{n} / \mathrm{a}$ & 2013 \\
\hline Slovenia & $100 \%$ [59] & $\mathrm{n} / \mathrm{a}$ & $\mathrm{n} / \mathrm{a}$ & $\mathrm{n} / \mathrm{a}$ & $\mathrm{n} / \mathrm{a}$ & 2013 \\
\hline
\end{tabular}

${ }^{\mathrm{a}}$ Data taken from OECD, if not otherwise indicated

${ }^{b}$ Authors' calculations based on data from countries' Statistical Office or Health Insurance Fund reports

people. Among the reasons, unaffordability (too expensive), too long distance to travel or long waiting lists are mentioned [38].

In the Czech Republic and Hungary, when it comes to utilization rates and access to health services of specific population groups, the Roma are disadvantaged compared to non-Roma (see last column of Table 12). Moreover, in Poland, the poorest uninsured people receive mostly inpatient care and they have limited access to primary care or dental services in practice [37].

\section{Discussion}

This section examines the plausible effects of the institutional design features on performance, i.e. progress towards UHC.

Table 10 O० expenditure

\begin{tabular}{|c|c|c|c|}
\hline \multirow[t]{2}{*}{ Country } & \multicolumn{2}{|l|}{ OOPs as $\%$ of THE ${ }^{a}[48]$} & \multirow[t]{2}{*}{ OOP expenditure as a share of household expenditure by income quintile/decile } \\
\hline & $\begin{array}{l}\text { (in the year after the introduction of } \\
\text { the government budget transfers) }\end{array}$ & (in 2013) & \\
\hline Croatia & $13.5(1995)^{b}$ & 12.5 & OOPs represent a heavy burden for some financially most vulnerable groups [50] \\
\hline $\begin{array}{l}\text { Czech } \\
\text { Republic }\end{array}$ & $5.2(1993)[60]$ & 15.7 & Low OOPs distributed relatively evenly across household income decile [24] \\
\hline \multirow[t]{2}{*}{ Estonia } & $19.9(2000)$ & 18.9 & $\begin{array}{l}\text { People from lower quintiles spent proportionally more than those from higher } \\
\text { quintiles. OOPs of } 1 \text { st quintile almost exclusively spent on medicines. 5th quintile } \\
\text { spent more on medicines and outpatient care. }\end{array}$ \\
\hline & & & $\begin{array}{l}\text { 1st income quintile: households with individuals } 65 \text { years or older or with disabilities } \\
\text { or chronic diseases face an increasing risk of relatively high expenditure [16] }\end{array}$ \\
\hline \multirow[t]{3}{*}{ Hungary } & 10.9 (1991) [52] & 27.5 & 2008: \\
\hline & & & 1st income quintile: $7.3 \%$ of income spent on OOPs (compared to $6.1 \%$ in 2005) \\
\hline & & & 5th income quintile: $2.5 \%$ of income spent on OPPs (compared to $2.2 \%$ in 2005) [43] \\
\hline Poland & $29.9(2000)$ & 22.8 & $\mathrm{n} / \mathrm{a}$ \\
\hline Slovakia & $11.5(1995)$ & 22.1 & $\begin{array}{l}\text { Increase in OOPs due to user fee introduction and higher co-payments in } 2003 \\
\text { affected the poor much more than the wealthy [22] }\end{array}$ \\
\hline Slovenia & $11.2(1995)^{c}$ & 12.2 & $\mathrm{n} / \mathrm{a}$ \\
\hline
\end{tabular}

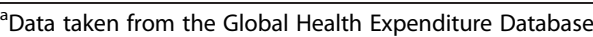

${ }^{b}$ Data for 1994 was not found and the Global Health Expenditure Database provides data starting with 1995

'Data for 1993 was not found and the Global Health Expenditure Database provides data starting with 1995 
Table 11 Incidence of catastrophic and impoverishing expenditure

\begin{tabular}{|c|c|c|}
\hline Country & $\%$ of households faced with catastrophic expenditure & $\%$ of households faced with impoverishing expenditure \\
\hline Croatia & 2009: $7.6 \%[61]$ & $\mathrm{n} / \mathrm{a}$ \\
\hline \multirow[t]{5}{*}{ Czech Republic } & 1999: 0 \% (this reflects the low levels of cost-sharing) [62] & \multirow[t]{5}{*}{$\mathrm{n} / \mathrm{a}$} \\
\hline & 2007: $8.1 \%$ & \\
\hline & 2008: $13 \%$ & \\
\hline & 2009: $11.9 \%$ & \\
\hline & (at a threshold of $5 \%$ of net income) [63] & \\
\hline \multirow[t]{14}{*}{ Estonia } & 2000-2007: Approx. 2-4 \% [16] & 2000: $3.7 \%$ \\
\hline & 2009: $1.6 \%[61]$ & 2007: $2.1 \%[36]$ \\
\hline & Threshold of $40 \%$ : & For the 1st quintile: \\
\hline & 2000: $1.8 \%$ & 2000: $4.6 \%$ \\
\hline & 2001: $1.9 \%$ & 2001: $4.6 \%$ \\
\hline & 2002: $2.1 \%$ & 2002: $5.7 \%$ \\
\hline & 2003: $2.1 \%$ & 2003: $5.8 \%$ \\
\hline & 2004: $3.0 \%$ & 2004: $8.4 \%$ \\
\hline & 2005: $2.8 \%$ & 2005: $3.5 \%$ \\
\hline & 2006: $4.4 \%$ & 2006: $7.8 \%$ \\
\hline & 2007: $2.3 \%$ & 2007: $4.6 \%$ [42] \\
\hline & 2010: $1.8 \%$ & 2010-2012 average for the 1st quintile: approx. $3 \%$ \\
\hline & $2011: 1.4 \%$ & \multirow{2}{*}{$\begin{array}{l}\text { 2000-2007: approx. } 5 \% \text { of single pensioners pushed below } \\
\text { poverty line due to OOPs (compared to approx. } 1 \% \text { in } \\
\text { 2010-2012) [64] }\end{array}$} \\
\hline & 2012: $2.1 \%$ [64] & \\
\hline \multirow[t]{2}{*}{ Hungary } & 2003: $0.7 \%$ & 2003: $0.2 \%$ \\
\hline & 2007: $0.5 \%$ [17] & 2007: $0.1 \%$ [17] \\
\hline \multirow[t]{4}{*}{ Poland } & \multirow{2}{*}{$\begin{array}{l}\text { From } 2000 \text { to 2009: Incidence and intensity of catastrophic } \\
\text { expenditure in drugs increased and affected for most the poor [65] }\end{array}$} & 2000: $2.4 \%$ \\
\hline & & 2009: $1.4 \%$ \\
\hline & \multirow[t]{2}{*}{ 2009: $1.6 \%$ [61] } & $\begin{array}{l}63 \% \text { of the poor had drug expenditure and were } \\
\text { further impoverished }\end{array}$ \\
\hline & & $\begin{array}{l}37 \% \text { of people fell into poverty due to drug } \\
\text { expenditure [65] }\end{array}$ \\
\hline Slovakia & $\begin{array}{l}\text { Mean incidence of catastrophic health expenditure arising } \\
\text { from OOPs: } 0.6 \%[66]\end{array}$ & $\mathrm{n} / \mathrm{a}$ \\
\hline Slovenia & 2009: 0.1 \% [61] & $\mathrm{n} / \mathrm{a}$ \\
\hline
\end{tabular}

\section{Effects of eligibility and targeting}

Overall, all countries have both a very high total population enrolment rate as well as a high share of the exempt and non-contributors. These countries achieve practically universality in population coverage. This is despite the fact that there are large shares of the population outside formal sector employment, which in the logic of a "traditional" compulsory SHI would be the principle entry point for coverage. Yet, eligibility of the exempt is defined both broadly as well as specifically to capture those outside formal sector employment. High population coverage rates are effectively achieved by primarily applying an indirect targeting approach. Most important seems the inclusion of the (unregistered) unemployed, which captures a large part of those outside formal sector employment. However this is not the case in Poland, Slovenia and Estonia for the long-term employed. On the other hand, these countries have not chosen to "automatically" enrol all those outside the formal sector, possibly to avoid informality becoming attractive. As a result, population coverage is not $100 \%$ in that some few population groups and individuals remain uncovered. In sum, the specific definition of eligible groups for exemption is decisive for the level of population coverage. Interestingly, in most countries (Croatia, Czech Republic, Hungary, Poland, Slovakia), children are part of the state insured and their coverage is financed through government budget transfers, even though family insurance is in place in all the 7 countries studied here. This reduces in principle the degree of cross- 
Table 12 Utilization rates and unmet needs

\begin{tabular}{|c|c|c|c|}
\hline Country & $\begin{array}{l}\text { Equity between income } \\
\text { quintiles }\end{array}$ & Inequities for lower income quintiles & Inequities for specific groups \\
\hline \multirow[t]{2}{*}{ Croatia } & \multirow[t]{2}{*}{$\mathrm{n} / \mathrm{a}$} & $\begin{array}{l}\text { Lower utilization rates for GP, specialist } \\
\text { and dentist visits [44] }\end{array}$ & \multirow[t]{2}{*}{$\mathrm{n} / \mathrm{a}$} \\
\hline & & Higher share of unmet need ${ }^{a}(2012,[38])$ & \\
\hline Czech Republic & $\begin{array}{l}\text { Similar utilization rates for GP, } \\
\text { specialist and dentist visits } \\
(2008,[67])\end{array}$ & Higher share of unmet need ${ }^{a}(2012,[38])$ & $\begin{array}{l}44 \% \text { of Roma and } 11 \% \text { of non-Roma } \\
\text { population had no access to essential } \\
\text { drugs. } 87 \% \text { of Roma and } 99 \% \text { of } \\
\text { non-Roma population had access to } \\
\text { health services (2011, [33]) }\end{array}$ \\
\hline \multirow[t]{3}{*}{ Estonia } & \multirow[t]{3}{*}{$\mathrm{n} / \mathrm{a}$} & $\begin{array}{l}\text { Inequities in access to primary and dental } \\
\text { care, but declining (2004-2008, [36]) }\end{array}$ & \multirow[t]{3}{*}{$\mathrm{n} / \mathrm{a}$} \\
\hline & & Higher share of unmet need ${ }^{a}(2012,[38])$ & \\
\hline & & $\begin{array}{l}\text { For services requiring user charges (outpatient } \\
\text { drugs, dental care) there are more inequalities } \\
\text { in utilization by income level compared to } \\
\text { services with little need for OOPs (inpatient } \\
\text { care, emergency care) (2000-2007, [36]) }\end{array}$ & \\
\hline \multirow[t]{2}{*}{ Hungary } & \multirow[t]{2}{*}{$\begin{array}{l}\text { Equity in the probability of } \\
\text { seeing a GP }(2009,[67])\end{array}$} & $\begin{array}{l}\text { Inequity in utilization rates for dentist and } \\
\text { specialist visits }(2009,[67])\end{array}$ & \multirow{2}{*}{$\begin{array}{l}\text { Roma were less likely to use health } \\
\text { services, particularly those offered by } \\
\text { specialist and dentists. The use of health } \\
\text { services by Roma was similar to that seen } \\
\text { in the lowest income quintile of the general } \\
\text { population. (2007, [17]) }\end{array}$} \\
\hline & & Higher share of unmet need ${ }^{a}(2012,[38])$ & \\
\hline \multirow[t]{2}{*}{ Poland } & \multirow[t]{2}{*}{$n / a$} & Higher share of unmet need ${ }^{a}(2012,[38])$ & \multirow[t]{2}{*}{$\mathrm{n} / \mathrm{a}$} \\
\hline & & $\begin{array}{l}\text { Inequity in utilization rates for GP and dentist } \\
\text { visits }^{\mathrm{b}}(2009,[67])\end{array}$ & \\
\hline \multirow[t]{2}{*}{ Slovakia } & \multirow[t]{2}{*}{$\mathrm{n} / \mathrm{a}$} & Inequity in utilization rates for GP visits ${ }^{\mathrm{b}}(2009,[67])$ & \multirow[t]{2}{*}{$\mathrm{n} / \mathrm{a}$} \\
\hline & & Higher share of unmet need ${ }^{a}(2012,[38])$ & \\
\hline \multirow[t]{2}{*}{ Slovenia } & $\begin{array}{l}\text { Equity in access and utilization } \\
\text { rates [23] }\end{array}$ & $\mathrm{n} / \mathrm{a}$ & \multirow[t]{2}{*}{$\mathrm{n} / \mathrm{a}$} \\
\hline & $\begin{array}{l}\text { Equity in utilization rates for GP, } \\
\text { specialist and dentist visits }{ }^{\mathrm{b}} \\
(2007,[67])\end{array}$ & & \\
\hline
\end{tabular}

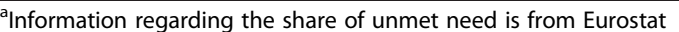

${ }^{b}$ Data on utilization of health care services by income level is adjusted for need

subsidization among contributors. It also further blurs the line between coverage of family dependents and otherwise vulnerable population groups financed through government budget transfers.

Yet, there are gaps in health insurance coverage of certain groups, and thus countries are undertaking efforts to reach these unreached groups. In Estonia, for example, since the end of 2002, individuals who might otherwise remain uninsured can acquire voluntary coverage when meeting the following eligibility criteria: Estonian residents who receive a pension fund from another country and individuals who are not currently eligible, but who have been members of the Estonian Health Insurance Fund for at least 12 months in the two years prior to applying for voluntary membership, as well as their dependents (students and people temporarily out of work but not registered as unemployed) [16].

In Poland, although people with low income are eligible for exemption, there are still uninsured poor individuals [37]. A reason for this might be the income threshold set by the authorities to establish the eligibility of individuals to be exempt. Despite being eligible, some groups such as the children of uninsured parents and homeless were not eligible for mandatory membership and did not have the capacity to pay contributions to join the system voluntarily before 2007 . Therefore, decision makers tried to identify those population groups of excluded people in order to provide access to care and coverage to them.

\section{Effects of financing and pooling arrangements}

The analysed health systems are strongly based on solidarity. Importantly, all countries have avoided fragmentation and allow for risk pooling by having established an integrated fund for both the exempted and the contributors. Moreover, the levels of state budget transfers are substantial in all countries, and found to be relatively high in Hungary and Slovakia for which data is available. State 
budget transfers are calculated on the basis of minimum wage, average wage or unemployment benefits or another defined amount, unless they represent a fixed amount of the budget. In general, unemployment benefits or the minimum wage are much smaller than the average wage, and thus using the average wage as assessment base leads to higher per capita budget transfers and potentially lower internal cross-subsidization. This also determines the level of equity in financing as well as the fund's financial sustainability.

For example, in Slovakia, state budget transfers amounted to about one third of total revenues of the SHI system, while about two thirds of the population are exempted (data for 2009, [22]). The Slovak SHI system is thus strongly based on cross-subsidization of contributors. Likewise in Estonia, there is a very high level of crosssubsidization within the pool where almost half of the insured population contribute, whereas state budget transfers are made for around $5 \%$ of the population, whilst the rest of the insured is cross-subsidized from within the pool, with everybody being entitled to the same benefit package [39]. Thus, in the long run, the system's financial fairness and sustainability might be threatened since the revenues largely come from contributions of the working population. In addition, the population is ageing and the share of working age individuals is decreasing [16]. Despite the recommendations by the Estonian Health Insurance Fund and WHO's specialists in 2009 to extend the public revenue base, i.e. apply the social tax to non-wage income and to introduce government budget transfers on behalf of pensioners [40], the Estonian Government did not choose to implement this reform option [41].

\section{Effects of benefit package design}

The benefit package design and, equally important, the cost-sharing mechanisms determine the degree of financial protection and utilization of health care services. In fact, in most countries (Croatia, Estonia, Hungary, Poland and Slovakia), there is inequity in access for lower income quintiles. In all of these countries, this is a result of unaffordable co-payments, especially for prescribed drugs, with the low income people being the most affected [18, 22, 36, 42-44].

After the transition and the shift to the new financing arrangement, combining SHI contributions and state budget transfers, OOPs increased in the Czech Republic, Hungary, Slovakia and Slovenia (Table 10) as a result of high utilization or overutilization of health care services $[16,17,22,24]$. Hungary and Slovakia tried to manage utilization by introducing cost-sharing mechanisms $[17,22]$, but they were not successful in reducing over-utilization. In contrast Slovenia increased copayments with only a small impact on access to health care and financial protection [21, 23], moreover since a policy on voluntary health insurance helped to cover user charges [45].

In Poland, uninsured poor individuals have free access to publicly financed services, yet this does not solve the challenge that poor people have no means to buy drugs for example, and thus, even if not always necessary, they prefer hospitalization care, where drugs are included.

\section{Conclusions}

This paper explored the trends and patterns of institutional design aspects of the existing financing arrangements, that is the mix of compulsory SHI contributions and state budget transfers with a focus on population groups outside formal sector employment and especially vulnerable population groups. Notably, the analysis revealed more commonalities than differences across countries. First of all, in all countries, vulnerable groups are fully exempted from paying contributions. The main challenge here is to ensure that the amount of transfers in combination with payroll contributions as a function of taxation policy are sufficient and allow for sustainability of the health insurance system in the long run.

Second, all countries avoided fragmentation by having established integrated pools for both the exempted and contributors. This allowed for risk pooling and strong redistributive capacity. Additionally, coverage is mandatory for both the exempted and the contributors with no opt out option of the system, with the exception of a few contributing groups in Estonia and Poland.

Third, the benefit packages are relatively comprehensive and, more importantly, all insured individuals, exempted as well as contributing, are entitled to the same benefit package. In most countries, this is combined with exemptions from cost-sharing for several, though not all, exempted groups. Concerns, though, remain for some of the vulnerable groups specifically that are not exempted from cost-sharing, and options need to be found such that they do not face difficulties in access to and utilization of health care services.

In terms of progress towards UHC, all countries have a very high total population enrolment rate (above $90 \%$ ). Yet, there are still groups not eligible for exemption and immediate measures within the same exemption logic should be taken in this regard. There are also challenges with respect to financial protection, because in half of the countries (Croatia, Estonia, Hungary, Slovakia), lower income quintiles face a heavy burden of OOPs.

Further research should be conducted to analyse the impact of these arrangements with respect to UHC progress on the basis of which to explore options how to improve coverage, especially for vulnerable groups. Governments should take further steps in better defining, identifying and exempting the potential vulnerable groups (e.g. the very poor, unregistered unemployed). Another question is how 
they can address the issue of system sustainability. Moreover, differentiated data for the exempt versus contributors, insured versus uninsured, and across income quintiles is needed. Providing answers to all these questions may help countries to deepen their achievements in UHC.

Overall, this analysis suggests that the government revenue transfer arrangements for selected and in particular vulnerable groups who are exempt from contributions, have been an effective way to set up a social health insurance that avoided coverage gaps for those outside the formal sector. This mixed financing system has thus made it possible to largely maintain their population coverage level after the system transition. Together with country experiences from other regions, it confirms that this approach of exempting vulnerable groups from contributions, or as termed elsewhere their subsidization, is one option to progress towards universal health coverage, contingent upon conducive institutional design.

\section{Additional file}

Additional file 1: Analytical Framework. Provides a detailed explanation of Table 1 based on which the analytical framework was developed [13, 14, 20, 21, 46, 68-73]. (PDF 35 kb)

\section{Abbreviations}

GDP: gross domestic product; GGHE: general government health expenditure; GP: general practitioners; OECD: Organization for Economic Cooperation and Development; OOP: out-of-pocket payments; SHI: social health insurance; THE: total health expenditure; UHC: universal health coverage; WHO: World Health Organization.

\section{Competing interests}

The authors declare that they have no competing interests.

\section{Authors' contribution}

IM conceived the study and its design with contributions from IV. IV undertook most of the literature review. Both authors undertook the analysis and interpretation of data and drafted the manuscript. Both authors have read and approved the final manuscript.

\section{Authors' information}

$\mathrm{IM}$ is a health systems development and health financing specialist in the Department of Health Systems Governance and Financing at the World Health Organization in Geneva. At the start of this research, IV was a master student at the University of Lausanne and then worked as a consultant within the same department at $\mathrm{WHO}$.

\section{Acknowledgements}

We gratefully acknowledge very valuable comments from Tamas Evetovis, Sarah Thomson and Benoit Mathivet. We also greatly benefited from discussions with Joe Kutzin and Matthew Jowett. The authors are responsible for all remaining errors. Finally, financial support to lleana Vilcu's consultant contract from the EU-WHO Universal Health Coverage Partnership Programme is gratefully acknowledged.

\section{Author details}

${ }^{1}$ Consultant with the World Health Organization from October 2014 to December 2015, Avenue Appia, 1211 Geneva, Switzerland. Department of Health Systems Governance and Financing, World Health Organization, Avenue Appia, 1211 Geneva, Switzerland.

Received: 12 August 2015 Accepted: 5 January 2016 Published online: 15 January 2016

\section{References}

1. Mossialos E, Dixon A. Funding health care: an introduction. In: Mossialos E, Dixon A, Figueras J, Kutzin J, editors. Funding health care: options for Europe. Buckingham, Philadelphia: Open University Press; 2002. p. 1-30.

2. Preker A, Jakab M, Schneider M. Health financing reforms in central and eastern Europe and the former Soviet Union. In: Mossialos E, Dixon A, Figueras J, Kutzin J, editors. Funding health care: options for Europe. Buckingham, Philadelphia: Open University Press; 2002. p. 80-108.

3. Davis C. Understanding the legacy: health financing systems in the USSR and central and eastern Europe prior to transition. In: Kutzin J, Cashin C, Jakab M, editors. Implementing health financing reform Lessons from countries in transition: WHO on behalf of the European Observatory on Health Systems and Policies; 2010. p. 25-63.

4. Meng Q, Yuan B, Jia L, Wang J, Yu B, Gao J et al. Expanding health insurance coverage in vulnerable groups: a systematic review of options. Health Policy and Planning. 2010:1-12. doi:10.1093/heapol/czq038

5. Acharya A, Vellakkal S, Taylor F, Masser E, Satija A, Burke M, et al. Impact of national health insurance for the poor and the informal sector in low- and middle-income countries: systematic review. London: EPPI-Centre, Social Science Research Unit, Institute of Education, University of London; 2012.

6. Bitran R. Universal health coverage and the challenge of informal employment. Lessons from developing countries. HNP discussion paper. Washington: World Bank; 2014

7. WHO. The World Health Report: Health Systems Financing: The path to universal coverage. Geneva: World Health Organization; 2010.

8. Blumenthal D, Mort E, Edwards J. The efficacy of primary care for vulnerable population groups. Health Services Research. 1995;30((1 Pt 2)):253-73.

9. World Bank. World Bank country classification [Available from: http://data. worldbank.org/about/country-classifications.

10. Kutzin J, Cashin C, Jakab M. Implementing health financing reform. Lessons from countries in transition. Copenhagen: WHO on behalf of the European Observatory on Health Systems and Policies; 2010.

11. World Bank. Country and lending group 2014 [Available from: http://data. worldbank.org/about/country-and-lending-groups\#High_income.

12. Mathauer I, Theisling M, Vilcu I, Mathivet B. Government budget transfers to health insurance arrangements to cover vulnerable and otherwise uninsured population groups: Institutional design patterns and challenges in low- and middle- income countries of the WHO European Region. Geneva, Switzerland : WHO, Department of Health Systems Governance and Financing; 2015.

13. Kutzin J. A descriptive framework for country-level analysis of health care financing arrangements. Health Policy. 2001;56:171-204.

14. Kutzin J. Health financing for universal coverage and health system performance: concepts and implications for policy. Bulletin WHO. 2013;91(8):602-11.

15. Kinkorova J, Topolcan O. Overview of healthcare system in the Czech Republic. The EPMA Journal. 2012;3(1):4.

16. Koppel A, Kahur K, Habicht T, Saar P, Habicht J, van Ginneken E. Estonia: Health system review. Health Systems in Transition. 2008;10:1-230.

17. Gaal P, Szigeti S, Csere M, Gaskins M, Panteli D. Hungary: Health system review. Health Systems in Transition. 2011:13:1-266.

18. Sagan A, Panteli D, Borkowski W, Dmowski M, Domanski F, Czyzewski M, et al. Poland: Health system review. Health Systems in Transition. 2011;13:1-193.

19. Nemec J, Cankar SS, Kostadinova D, Maly I, Darmopilova Z. How to finance health services: CEE experience with switch from "Semashko model" to health insurance systems. Paper prepared for the ICPP Panel 67. Grenoble: Comparative health reforms in Central and Eastern Europe: Europeanization versus subsidiarity.

20. Sheiman I, Langenbrunner J, Kehler J, Cashin C, Kutzin J. Sources of funds and revenue collection: reforms and challenges. In: Kutzin J, Cashin C, Jakab $M$, editors. Implementing health financing reform Lessons from countries in transition. Copenhagen: WHO on behalf of the European Observatory on Health Systems and Policies; 2010. 85-118.

21. Gotsadze G, Gaal P. Coverage decisions: benefit entitlements and patient cost sharing. In: Kutzin J, Cashin C, Jakab M, editors. Implementing health financing reform Lessons from countries in transition. Copenhagen: WHO on behalf of the European Observatory on Health Systems and Policies; 2010. 187-217.

22. Szalay T, Pazitny P, Szalayova A, Frisova S, Morvay K, Petrovic M, et al. Slovakia: Health system review. Health Systems in Transition. 2011;13:1-200.

23. Albreht T, Turk E, Toth M, Ceglar J, Marn S, Pribakovic Brinovec R, et al. Slovenia: Health system review. Health Systems in Transition. 2009;11:1-168.

24. Bryndova L, Pavlokova K, Roubal T, Rokosova M, Gaskins M, van Ginneken E. Czech Republic: Health system review. Health Systems in Transition. 2009;11:1-122. 
25. Kutzin J. Health financing for Universal Health Coverage. Addis Ababa, Ethiopia: European Union Regional Health and Education Seminar; 2013.

26. Statistical Office of the Slovak Republic. Statistical Yearbook of the Slovak Republic. 2012.

27. Estonian Health Insurance Fund. Annual report. 2012

28. Voncina L, Strizrep T, Bagat M, Pezelj-Duliba D, Pavic N, Polasek O. Croatian 2008-2010 health insurance reform: hard choices toward financial sustainability and efficiency. Croat Med J. 2012;53(1):66-76.

29. Svaljek S. The recent health reform in Croatia: True reforms or just a fundraising exercise? Health Policy. 2014;115((1)):36-43.

30. Jowett M. Revenue collection. Tunis, Tunisia: WHO Advanced Course on Health Financing for Universal Health Coverage; 2014.

31. Centre for International Reimbursements. Health care in the Czech Republic 2013 [Available from: http://www.cmu.cz/en/links-info-en/health-insurance-system-in-cz.

32. Kutzin J, Shishkin S, Bryndova L, Schneider P, Hrobon P. Reforms in the pooling of funds. In: Kutzin J, Cashin C, Jakab M, editors. Implementing health financing reform Lessons from countries in transition. Copenhagen: WHO on behalf of the European Observatory on Health Systems and Policies; 2010. p. 119-53.

33. European Roma Rights Centre. Czech Republic: Country profile 2011-2012.

34. Dotcho M. The health situation of Roma communities: Analysis of the data from the UNDP/World Bank/EC Regional Roma Survey 2011. Bratislava: Roma Inclusion Working Papers; 2012

35. Kuhlbrandt C, Footman K, Rechel B, McKee M. An examination of Roma health insurance status in Central and Eastern Europe. European Journal of Public Health. 2014;24(5):707-12.

36. Vork A, Habicht J, Xu K, Kutzin J. Income-related inequality in health care financing and utilization in Estonia since 2000. Copenhagen: WHO Regional Office for Europe; 2010

37. Marek M. Poland: Poverty and health. Poverty and social exclusion in the WHO European Region: health systems respond. Copenhagen: WHO Regional Office for Europe; 2010. p. 124-35.

38. Eurostat. SILC database 2013 [Available from: http://ec.europa.eu/eurostat/ web/health/health-care/data/database.

39. Habicht T, Habicht J. Estonia: "Good practice" in expanding health care coverage. In: Gottret P, Schieber GJ, Waters HR, editors. Good practices in health financing Lessons from reforms in low- and middle-income countries. Washington: The World Bank; 2008. p. 227-67.

40. Thomson S, Vork A, Habicht T, Roovali L, Evetovits T, Habicht J. Responding to the challenge of finanacial sustainability in Estonia's health system. Copenhagen: WHO Regional Office for Europe; 2010.

41. Thomson S, Habicht T, Roovali L, Evetovits T, Habicht H. Responding to the challenge of financial sustainability in Estonia's health system: one year on. Copenhagen: WHO Regional Office for Europe; 2011.

42. Vork A, Saluse J, Habicht J. Income-related inequality in health care financing and utilization in Estonia 2000-2007. Copenhagen: WHO Regional Office for Europe; 2009.

43. Baji P, Pavlova M, Gulacsi L, Groot W. Changes in equity in out-of-pocket payments during the period of health care reforms: Evidence from Hungary. International Journal for Equity in Health. 2012;11:36.

44. Pristas I, Bilic M, Pristas I, Voncina L, Krcmar N, Polasek O, et al. Health care needs, utilization and barriers in Croatia - Regional and Urban-rural differences. Coll Antropol. 2009;33:121-30.

45. Thomson S. What role for voluntary health insurance? In: Kutzin J, Cashin C, Jakab M, editors. Implementing health financing reform Lessons from countries in transition. Copenhagen: WHO on behalf of the European Observatory on Health Systems and Policies; 2010. p. 299-325.

46. Xu K. Distribution of health payments and catastrophic expenditures. Methodology. Discussion paper 2. Geneva: WHO; 2005.

47. Probst L, Mathauer I, Vilcu I. Government subsidization of health insurance type arrangements for vulnerable and informally employed population groups in Asian low- and middle-income countries: Institutional design patterns and implementation issues. Geneva, Switzerland: WHO, Department of Health Systems Governance and Financing; 2015.

48. WHO. Global Health Expenditure Database 2014 [Available from: http://apps. who.int/nha/database.

49. World Bank. World Data Bank 2014 [Available from: http://data.worldbank.org/.

50. Voncina L, Jemiai N, Merkur S, Golna C, Maeda A, Chao S, et al. Croatia: Health system review. Health Systems in Transition. 2006;8(7):1-108.

51. Saltman RB. Social health insurance in perspective: the challenge of sustaining stability. In: Saltman RB, Busse R, Figueras J, editors. Social health insurance systems in western Europe. Berkshire, England: Open University Press; 2004. p. 3-20.

52. Gaal P. Health care systems in transition: Hungary. Copenhagen: WHO Regional Office for Europe on behalf of the European Observatory on Health Systems and Policies; 2004.

53. Boulhol H, Sowa A, Golinowska S, Sicari P. Improving the health-care system in Poland. Economics Department working paper no. 957. OECD, 2012.

54. Hlavacka S, Wagner R, Riesberg A. Health care systems in transition: Slovakia. Copenhagen: WHO Regional Office for Europe on behalf of the European Observatory on Health Systems and Policies; 2004.

55. Health Insurance Institute of Slovenia. Compulsory health insurance 2009 [Available from: http://www.zzzs.si/zzzs/internet/zzzseng.nsf/o/ DB29291A87496668C1256E8900489918.

56. Voncina L, Dzakula A, Mastilica M. Health care funding reforms in Croatia: A case of mistaken priorities. Health Policy. 2007;80:144-57.

57. Couffinhal A, Habicht T. Health system financing in Estonia: situation and challanges in 2005. 2005. WHO Regional Office for Europe.

58. Croatian Bureau of Statistics. Statistical Yearbook of the Republic of Croatia. 2011.

59. OECD. OECD Health Data: Social Protection 2015 [Available from: http:// www.oecd-ilibrary.org/social-issues-migration-health/data/oecd-healthstatistics/oecd-health-data-social-protection_data-00544-en.

60. Rokosova M, Hava P, Schreyogg J, Busse R. Health care systems in transition: Czech Republic. WHO Regional Office for Europe on behalf of the European Observatory on Health Systems and Policies. 2005.

61. Scheil-Adlung $X$, Kuhl C. Social security for all: Addressing inequities in access to health care for vulnerable groups in countries of Europe and Central Asia. Geneva: International Labour Organization, Social Security Department; 2011.

62. Xu K, Evans DB, Kawabata K, Zeramdini R, Klavus J, Murray C. Household catastrophic health expenditure: a multicountry analysis. The Lancet. 2003; 362:111-17.

63. Krutilova V. Cost sharing of patients for health care - forms, extent, impacts. Brno: Masaryk University; 2013.

64. Vork A, Saluse J, Reinap M, Habich T. Out-of-pocket payments and health care utilization in Estonia, 2000-2012. WHO Regional Office for Europe: Copenhagen; 2014.

65. Luczak J, Garcia-Gomez P. Financial burden of drug expenditures in Poland. Health Policy. 2012;105:256-64.

66. Saksena P, Xu K, Durairaj V. The drivers of catastrophic expenditure: outpatient services, hospitalization or medicines? World Health Report 2010, Background Paper, 21. Geneva: WHO; 2010.

67. Devaux M, de Looper M. Income-related inequalities in health service utilisation in 19 OECD countries, 2008-2009, OECD Health Working Papers, No. 58. Paris: OECD Publishing; 2012.

68. Wang H, Switlick K, Ortiz C, Zurita B, Connor C. Health insurance handbook. How to make it work. Washington: World Bank; 2012.

69. Gwatkin DR. Are free government health services the best way to reach to poor? HNP discussion paper. Washington: World Bank; 2004.

70. Coady D, Grosh M, Hoddinott J. Targeting of transfers in developing countries: Review of lessons and experience. Washington: World Bank; 2004

71. Kutzin J. Conceptual framework for analyzing health financing systems and the effects of reforms. In: Kutzin J, Cashin C, Jakab M, editors. Implementing health financing reform Lessons from countries in transition. Copenhagen: WHO on behalf of the European Observatory on Health Systems and Policies: 2010. p. 3-24.

72. Normand C, Weber A, Carrin G, Doetinchem O, Mathauer I, Scheil-Adlung X et al. Social health insurance. A guidebook for planning. Asian Development Bank, International Labour Organization, World Health Organization, German Technical Cooperation 2009.

73. Witter S. Health financing in developing and transitional countries. Briefing paper for OXFAM. York: University of York; 2002. 